\title{
Cash-strapped ANZAAS is set for closure
}

[ADELAIDE] The 109-year-old Australian and New Zealand Association for the Advancement of Science (ANZAAS) announced last week that it lacks sufficient funds to continue operating. The association has been beset by falling membership and declining attendance at its congresses.

The association sustained a heavy loss on its 1996 congress in Canberra, and last week's congress in Adelaide, South Australia, only broke even. Chairman Bruce McKellar, dean of science at the University of Melbourne, is to recommend to a special general meeting in December that it be wound up.

Created as an offshoot of the British Association for the Advancement of Science in 1888 when Australia was a colony, ANZAAS gave coherence and identity to the emerging scientific communities both of Australia and of New Zealand, which hosted a congress every decade.

Congresses attracted the largest gatherings of scientists in Australia and New Zealand, with a wide range of specialized sections and, uniquely in the scientific calendar, crossdisciplinary sessions and forums on policy and social issues. But after the Melbourne congress in 1985 and the last in New Zealand in 1987, attendances fell sharply.

One factor has been a rapid growth in specialist conferences held at the same time. Last week, for example, the Australian Society for Microbiology also met in Adelaide, drawing 900 paying delegates. By contrast, sessions at ANZAAS had audiences of 10 to 20. The general registration of 220 indicated

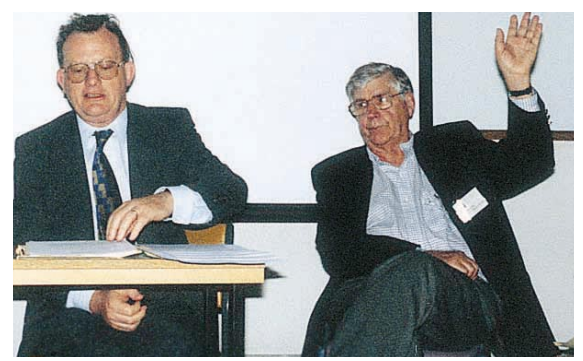

Beginning of the end? Chairman McKellar (left) plans to ask for ANZAAS to be wound up.

no resurgence of interest and finance in the long term.

Local organizers had had to use volunteer labour, as the federal government initially refused to provide the congress's normal grant. Under pressure, Peter McGauran, the science minister, relented. But his offer of A $\$ 14,000$ (US\$10,000) was too small and too late to make a difference.

The turning point came when the ANZAAS council suddenly had to cancel the 1998 meeting in Hobart, Tasmania, just as it was due to be publicized at Adelaide. Con-

venor Jim Reid of the University of Tasmania says that it withdrew in the face of competition for government funds and corporate sponsorship. Another factor was a challenge from Australian Science Communicators, a media group dissatisfied with ANZAAS.

With no congress next year, ANZAAS's position became hopeless. The viability of its official journal, Search, Australia's only science magazine, is also threatened and a rescue campaign has begun, supported by Sir Gustav Nossal, president of the Australian Academy of Science.

Some link the demise of ANZAAS with McGauran's forced resignation in the same week (see Nature 389,$427 ; 1997$ ) as indicating malaise in the public standing of science in Australia. But Nossal hopes that a new organization, representating individual scientists, may rise from the ashes of ANZAAS.

McKellar is recommending that the organization pass its remaining funds of A $\$ 100,000$ to organizations with "similar aims" in the promotion and public understanding of science.

Peter Pockley Cabinet minister takes over Australian science portfolio

[ADELADEE] Prime Minister John

Howard announced last weekend that John Moore, the cabinet minister in the Ministry for Industry, Science and Tourism, will take on the responsibilities of Peter MoGauran, who resigned last week as science minister (see above).

In a reshuffle which was prompted by three ministerial resignations, controversial education minister Amanda Vanstone has been replaced by the former minister for schools, David Kemp. A former professor of political science, Kemp is expected to show himself more knowledgeable about the workings of universities. He is considered to be an economic hardliner.

\section{Plagiarism claims turn spotight on US Navy's misconduct policy}

[SAN DIEGO] A psychologist alleged to have plagiarized at least three books has been picked to head the research office at a major US Navy facility. The appointment raises questions about how the Navy deals with cases of scientific misconduct.

Dennis L. Reeves, who is 46 , was named in August as head of the Clinical Investigation Department at the Naval Medical Center in San Diego, California, which monitors a broad array of research at several institutions in the region.

The promotion occurred at a time when the state of Maryland, where Reeves received his psychology licence, was considering taking disciplinary action because of the long-simmering charges of plagiarism. A psychologist licensed in one state can practise at any Navy facility.

Reeves has apologized to some of the authors in letters for what he termed inadvertent "borrowing" of material that was not "adequately attributed". Reeves and his superiors declined to be interviewed.
Like many US institutions, the Navy has no specific policy on probes into scientific misconduct. Edie Rosenthal, a Navy spokeswoman, says there are no plans to develop such a policy, because "our judicial system works well" on such matters.

The Navy examined some aspects of the issue in 1994 when the allegations first surfaced, deciding then that there was no plagiarism. But Navy records and interviews indicate that the inquiry was limited in scope. A colleague of Reeves examined the allegation, deciding in November 1994 there was only "editorial and style error".

But the Navy apparently did not scrutinize the remainder of the book, The Clinical Assessment of Memory: A Practical Guide, by Reeves and Danny Wedding, a psychologist at the University of Missouri who directs the Missouri Institute of Mental Health in St Louis.

Shortly after it was published by Springer Publishing Co. of New York, a nationally renowned psychologist, Muriel D.
Lezak, claimed that the book included sections from one of her books published by Oxford University Press (OUP).

After demands from OUP, Springer ceased distribution of the Reeves/Wedding book in August 1995, destroyed the remaining copies and paid Lezak a $\$ 2,000$ settlement. "Plagiarism is very high on my list of disgusting acts," commented Lezak, of the Oregon Health Sciences University.

She says she later discovered that parts of the Reeves/Wedding book included passages from psychologists at Harvard University, the Mayo Clinic in Minnesota and the University of California at San Diego.

Several of these authors complained to OUP. They also complained to the American Psychological Association (APA) about Wedding, who, unlike Reeves, is an APA member. Both Wedding and the APA refused to say what action, if any, was taken.

Although credited as co-author, Wedding says he wrote only two chapters, and neither included plagiarized material.

Rex Dalton 